\title{
Identification and characterization of heteroclitic peptides in TCR-binding positions with improved HLA-binding efficacy
}

\author{
Beatrice Cavalluzzo ${ }^{1 \dagger}$, Concetta Ragone ${ }^{1 \dagger}$, Angela Mauriello ${ }^{1}$, Annacarmen Petrizzo ${ }^{1}$, Carmen Manolio ${ }^{1}$, \\ Andrea Caporale ${ }^{2,3}$, Luigi Vitagliano ${ }^{2}$, Menotti Ruvo ${ }^{2}$, Luigi Buonaguro ${ }^{1}$ and Maria Tagliamonte ${ }^{1 *}$ (D)
}

\begin{abstract}
The antigenicity as well as the immunogenicity of tumor associated antigens (TAAs) may need to be potentiated in order to break the immunological tolerance. To this aim, heteroclitic peptides were designed introducing specific substitutions in the residue at position 4 (p4) binding to TCR. The effect of such modifications also on the affinity to the major histocompatibility class I (MHC-I) molecule was assessed. The Trp2 antigen, specific for the mouse melanoma B16F10 cells, as well as the HPV-E7 antigen, specific for the TC1 tumor cell lines, were used as models. Affinity of such heteroclitic peptides to HLA was predicted by bioinformatics tools and the most promising ones were validated by structural conformational and HLA binding analyses. Overall, we demonstrated that TAAs modified at the TCR-binding p4 residue are predicted to have higher affinity to $M H C-I$ molecules. Experimental evaluation confirms the stronger binding, suggesting that this strategy may be very effective for designing new vaccines with improved antigenic efficacy.
\end{abstract}

\section{Introduction}

Tumor associated antigens (TAAs) are cellular selfantigens mostly overexpressed in cancer cells with low expression in normal cells. For this reason, they may be subject to both central and peripheral tolerance mechanisms leading to an inefficient immune response. Indeed, TAA-based cancer vaccines are well tolerated and have minimal side effects but have been proven to have limited efficacy in clinical trials [1]. Recognition of target non self-antigens by $\mathrm{T}$ cells is mediated by interaction between the $\mathrm{T}$ cell receptor (TCR) and the peptideMHC-I complex (pMHC). In such interaction, the peptide is fastened to the MHC-I groove through the amino

\footnotetext{
*Correspondence: m.tagliamonte@istitutotumori.na.it †Beatrice Cavalluzzo and Concetta Ragone contributed equally to this work

${ }^{1}$ Innovative Immunological Models Lab, Istituto Nazionale Tumori "Fond. G. Pascale", Via Mariano Semmola, 1, 80131 Naples, Italy

Full list of author information is available at the end of the article
}

acid residues at the "anchor positions" while exposing the complementary "TCR-binding" residues to the TCR. Deciphering the different MHC-I binding motifs enabled the definition of the preferred peptide residues at the anchor positions for each HLA allele [2-5]. Heteroclitic peptides have been designed to enhance the stability of the pMHC-I complex as well as to increase the immunogenicity of the bound peptide [6-13].

An alternative approach for improving the immunogenicity of natural TAAs is to generate heteroclitic peptides mutated in the TCR-binding residues. The aim is to generate an epitope which is sufficiently different from the natural wild-type peptide presented by the cancer cells in order to break the immunological tolerance and induce a more potent $\mathrm{CD}^{+} \mathrm{T}$ cell response. However, such a difference should not be too extensive for the cellular immune response to retain the capability of cross-recognizing the natural structure and killing the presenting tumor cells $[10,11,14-19]$. Indeed, the low



(c) The Author(s) 2021. This article is licensed under a Creative Commons Attribution 4.0 International License, which permits use, sharing, adaptation, distribution and reproduction in any medium or format, as long as you give appropriate credit to the original author(s) and the source, provide a link to the Creative Commons licence, and indicate if changes were made. The images or other third party material in this article are included in the article's Creative Commons licence, unless indicated otherwise in a credit line to the material. If material is not included in the article's Creative Commons licence and your intended use is not permitted by statutory regulation or exceeds the permitted use, you will need to obtain permission directly from the copyright holder. To view a copy of this licence, visit http://creativeco mmons.org/licenses/by/4.0/. The Creative Commons Public Domain Dedication waiver (http://creativecommons.org/publicdomain/ zero/1.0/) applies to the data made available in this article, unless otherwise stated in a credit line to the data. 
affinity between the TCR and the peptide-major histocompatibility complex (pMHC) allows the T-cell receptor to cross-react with multiple pMHCs [20-22].

In the present study, Trp2 and HPVE7 peptides, expressed by mouse melanoma B16F10 and TC1 tumor cell lines, respectively, were modified with different amino acid substitutions at the TCR-binding residue at position $4(\mathrm{p} 4)$. Bioinformatics tools were used to predict and evaluate the impact of these amino acidic replacements on the antigen-MHC recognition. Moreover, experimental data demonstrated that even a mutation of a TCR-binding residue may increase the affinity for the $\mathrm{MHC}$ receptor. Based on these observations, we propose a rather simple strategy for developing vaccine antigens with improved antigenic efficacy.

\section{Materials and methods}

\section{Prediction and design of heteroclitic peptides}

Heteroclitic peptides for Trp2 and HPV E7 antigens were designed introducing each of the 20 genetically encoded amino acids at each position of the peptides. The predicted binding affinity of each heteroclitic peptide to the $\mathrm{H} 2-\mathrm{Db}$ was assessed by the NetMHCpan version 4.0 algorithm. Only mutations of the TCR-binding $\mathrm{p} 4$ residue (Tyr) predicted to have a higher affinity for the MHC compared to the wt peptide were selected for the experimental evaluation.

\section{Peptide synthesis}

Individual peptides were synthesized at a purity $>95 \%$ determined by LC-MS analyses, as previously reported [23]. Lyophilized powder was dissolved in dimethyl sulfoxide (DMSO; Sigma-Aldrich), diluted in phosphatebuffered saline $(1 \times$ PBS; Gibco Life Technologies $)$ and stored at $-80^{\circ} \mathrm{C}$ until use.

\section{Peptide binding affinity assay}

Peptide binding affinity to $\mathrm{H} 2-\mathrm{Db}$ molecule was performed for each selected peptide. Tap-deficient mouse derived H-2Db RMA-S cells were cultured for $24 \mathrm{~h}$ at $26{ }^{\circ} \mathrm{C}$ to accumulate empty MHC-I molecules on the cell surface [24]. Cells were washed in serum-free medium and incubated at $3 \times 10^{5}$ cells/well with varying concentrations of peptides $(1 \mu \mathrm{M}, 5 \mu \mathrm{M}, 10 \mu \mathrm{M})$ for $4 \mathrm{~h}$ at $37{ }^{\circ} \mathrm{C}$ with $5 \% \mathrm{CO}_{2}$. Cells were harvested, washed with phosphate-buffered saline $(1 \times \mathrm{PBS}$; Gibco Life Technologies), stained with anti-H-2Db fluorescent monoclonal antibody (cat. 1157535; SONY) and analyzed by flow cytometry. All the experiments were performed in triplicate.

\section{Molecular docking of the E7 wt and Trp2 peptides and their heteroclitic variants with the $\mathrm{H}-2$ class I histocompatibility antigen $\mathrm{H}-2 \mathrm{Db}$}

To perform molecular docking analysis of the complex between the major histocompatibility complex class I (MHC-I) $\mathrm{H}-2 \mathrm{Db}$ and the HPV-16 E7, Trp2 peptides and their heteroclitic variants, the structural data available for $\mathrm{H}-2 \mathrm{Db}$ was searched in the Protein Data Bank (PDB) (https://www.rcsb.org/). Although several structures of this murine MHC-I complexed with variety of peptides have been reported, no structural data is specifically available for the specific $\mathrm{H}-2 \mathrm{Db} / \mathrm{HPV}-16-\mathrm{E} 7$ as well as for $\mathrm{H}-2 \mathrm{Db} / \mathrm{Trp} 2$ complexes. In this scenario, the PDB database was queried for complexes of $\mathrm{H}-2 \mathrm{Db}$ with peptides sharing some sequence similarity with HPV-16 E7 and Trp2 epitopes. A promising candidate was the PDB entry 1FG2 that corresponds to a complex of $\mathrm{H}-2 \mathrm{D}^{\mathrm{b}}$ with the LCMV peptide with sequence KAVYNFATC [25]. The molecular modelling and docking analysis was performed by PyMOL and MolSoft molecular graphics systems.

\section{Results}

\section{Prediction and design of heteroclitic peptides}

An overall $171(9 \times 19)$ variants of the wild type sequence of Trp2 and HPV E7 epitopes were generated by placing in each position of the peptides all 20 amino acids leaving in the other positions the original residue. Prediction binding to the $\mathrm{H}-2 \mathrm{Db}$ major histocompatibility complex I (MHC-I) was obtained for all the heteroclitic epitopes with the algorithm NetMHCpan 4.0. Most of them were predicted to have a binding to $\mathrm{H}-2 \mathrm{Db}$ lower than the wt sequence, while a set of 47 (Trp2) and 45 (E7) heteroclitic epitopes showed a binding higher than the wt (Fig. 1a, b).

Among the latter set of epitopes, those modified in the TCR-facing position $4(\mathrm{p} 4)$ were selected for in vitro validation. Interestingly, the modification of the p4, which does not directly interact with the $\mathrm{H}-2 \mathrm{Db}$ molecule, had significant impact on the binding of the epitope. This was evident for both epitopes, but was more dramatic for the Trp2 which is a very poor binder in the wt form $(6990 \mathrm{nM})$, and gained up to a 9.5-fold increase in the binding affinity to the $\mathrm{H}-2 \mathrm{Db}$ molecule $(735 \mathrm{nM})$, although remaining a weak binder [17, 18] (Fig. 2a, b). In the HPV-E7 peptide, all the amino acid substitutions for the polar Tyrosine (Tyr, Y) were predicted to 




significantly improve the binding affinity to $\mathrm{H} 2-\mathrm{Db}$ molecule, regardless the chemical property of side chains. The best improvement was observed when the substitution involved either the non-polar Valine (Val, V) or the polar Glutamine (Gln, Q). The only exception was the nonpolar Tryptophan (Trp, W) which did not induce a significant improvement in the binding affinity. Similar pattern was observed for the Trp2 peptide, and also in this case the best improvement was observed when the polar Glutamine (Gln, Q) substituted the negative charged Aspartic Acid (Asp, D) (Fig. 3).

\section{Structure modelling}

The impact of the amino acid substitutions on the structure of the heteroclitic peptides as well as the interaction with the $\mathrm{H} 2-\mathrm{Db}$ molecule, was assessed by structure modelling and molecular docking. We preliminarily modelled the complexes formed by the E7 and Trp2 peptides with $\mathrm{H}-2 \mathrm{Db}$ using the structure of these $\mathrm{MHCI}$ with the peptide KAVYNFATC (PBD entry 1F2) as template. Interestingly, the E7 epitope shares with the peptide of the complex an Asn residue in position 5 (N5) that represents a key anchoring point of the epitope on the $\mathrm{H} 2-\mathrm{Db}$ 


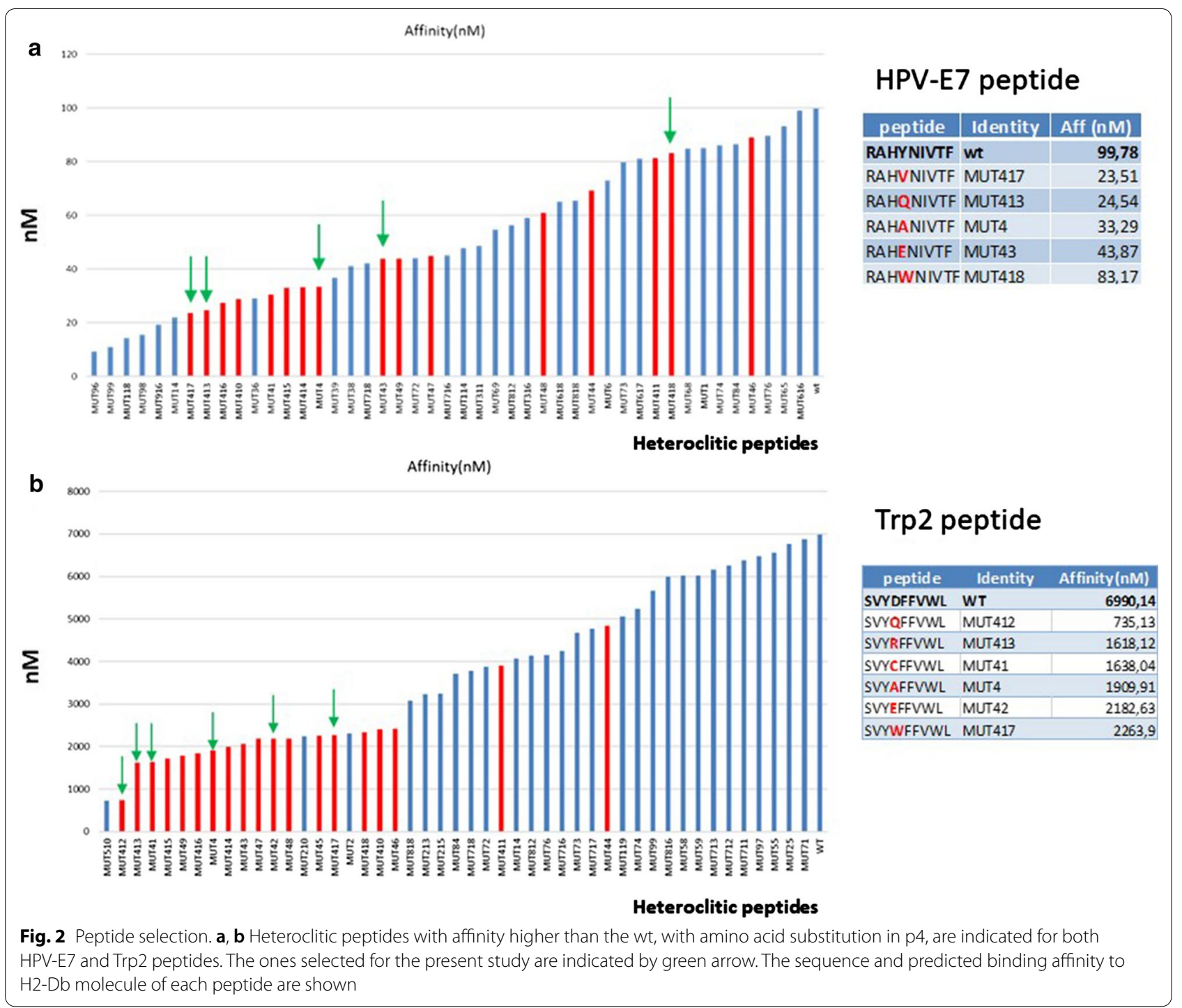

molecule. On the contrary, the weak binder Trp2 peptide has a totally different conformational structure as the side chain of the residue in position 5 (F5) could not be easily allocated in the H2-Db pocket (Fig. 4a). The latter observation is confirmed by the lack of hydrogen bond formation between the F5 of Trp2 and the Q70/Q97 residues of $\mathrm{H} 2-\mathrm{Db}$ which are those interacting with the $\mathrm{N} 5$ of 1FG2 and E7 peptides (Fig. 4b).

\section{Molecular docking}

In order to verify whether the substitutions of the residue in $\mathrm{p} 4$ do impact on the interactions with the $\mathrm{H} 2-\mathrm{Db}$, molecular docking simulations were performed. The results show that none of the substitutions introduced in the $\mathrm{p} 4$ residue of the HPV-E7 peptide significantly changes the front as well as rear contact points of the E7 peptide with the $\mathrm{H} 2-\mathrm{Db}$ molecule. The only exception is the Y4Q substitution, which shows a loss of contact in the rear face at the $\mathrm{p} 3 / \mathrm{p} 4$ tract (Fig. 5a). However, the amino acid pattern exposed to the TCR by each heteroclitic peptide, when docked into the $\mathrm{H} 2-\mathrm{Db}$ groove, shows significant differences compared to the wt. Indeed, only the Y4V substitution results in a conformation of the TCR binding residues very similar to the wt peptide (Fig. 5b).

Likewise, all the substitutions introduced in the heteroclitic peptides of the Trp2 epitope show an identical pattern of contact points with the H2-Db of the wt peptide (Fig. 6a). Accordingly, the amino acid pattern exposed 


\begin{tabular}{l}
\hline \multicolumn{2}{|c|}{ HPV-E7 peptide } \\
\begin{tabular}{|l|r|}
\hline peptide Identity & Aff (nM) \\
\hline RAHYNIVTF wt & 99,78 \\
\hline RAHVNIVTF MUT417 & 23,51 \\
\hline RAHONIVTF MUT413 & 24,54 \\
\hline RAHANIVTF MUT4 & 33,29 \\
\hline RAHENIVTF MUT43 & 43,87 \\
\hline RAHWNIVTF MUT418 & 83,17 \\
\hline
\end{tabular}
\end{tabular}

\section{Trp2 peptide}
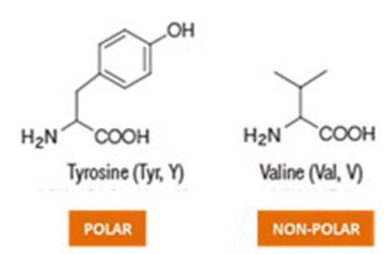

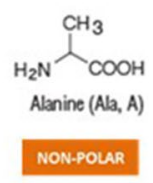

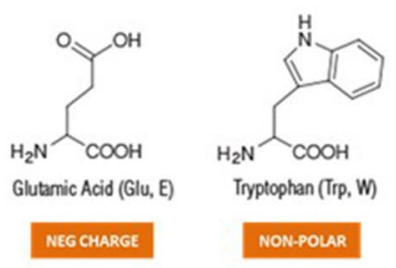
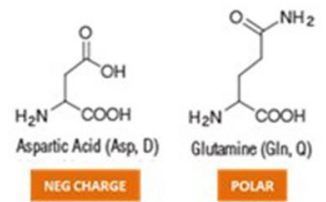
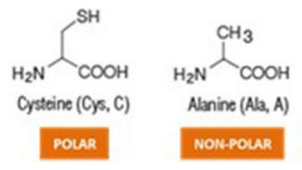

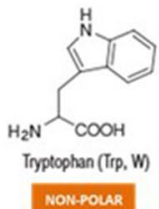

Fig. 3 Structure of the amino acid residues at p4 in heteroclitic peptides. The structure of the substituting amino acid residues at p4 in the selected heteroclitic peptides is shown, together with the chemical properties of the side chains

to the TCR by each heteroclitic peptide, when docked into the $\mathrm{H} 2-\mathrm{Db}$ groove, shows a substantial similarity compared to the wt. Indeed, only the D4R and the D4W substitutions result in a conformation of the TCR binding residues significantly different from the wt peptide (Fig. 6b).

\section{In vitro analysis of peptide binding affinity and stability to $\mathrm{H}-2 \mathrm{Db}$ molecule}

In order to experimentally confirm the binding of heteroclitic peptides to $\mathrm{H}-2 \mathrm{Db}$ molecule, the $\mathrm{H}-2 \mathrm{Db}$ positive RMA-S cell line was loaded with different concentrations $(1 \mu \mathrm{M}, 5 \mu \mathrm{M}, 10 \mu \mathrm{M})$ of selected heteroclitic peptides modified in $\mathrm{p} 4$ with a predicted affinity higher than the wt peptide. The heteroclitic peptides of the E7 epitope, except for the Y4E substitution, showed a binding to the $\mathrm{H}-2 \mathrm{Db}$ stronger than the wt peptide, although the correlation with predicted binding was low. Indeed, the Y4W substitution, predicted to have a binding similar to the wt, showed the strongest binding in the assay (Fig. 7a, b). Similarly, most of the heteroclitic peptides of the Trp2 epitope showed a binding to the $\mathrm{H}-2 \mathrm{Db}$ stronger than the wt peptide, although the correlation with predicted binding was low. Also in this case, the substitutions D4W, D4C and D4E showed a binding lower than the wt although they were predicted to have a higher binding (Fig. 7c, d).

\section{Discussion}

In the present study, we set up a simple strategy to design epitope variants with increased affinities for the $\mathrm{H} 2-\mathrm{Db}$ molecule. Heteroclitic peptides were designed with amino acid changes in one of the TCR-facing residues (p4) which does not have direct contacts with the $\mathrm{H} 2-\mathrm{Db}$ molecule. Such substitutions were predicted to impact on the peptide binding to the murine $\mathrm{H} 2-\mathrm{Db}$ molecule and, in particular, several of them induce an increased affinity. The two peptides used in the analysis, Trp2 and HPV-E7 peptides, are predicted to have dramatically different binding affinity to $\mathrm{H} 2-\mathrm{Db}$ molecule $(6990 \mathrm{nM}$ and $100 \mathrm{nM}$, respectively). Bioinformatics structural analyses confirm such a difference, showing that the structure of the residue in the anchor positions (p5) of the Trp2 peptide has a very poor compatibility with the $\mathrm{H} 2-\mathrm{Db}$ groove.

Molecular docking shows that, with the exception of the $\mathrm{Y} 4 \mathrm{Q}$, none of the other substitutions introduced in the p4 residue of the HPV-E7 peptide significantly changes the contact points of the E7 peptide with the $\mathrm{H} 2-\mathrm{Db}$ molecule. However, only the Y4V substitution, when docked into the $\mathrm{H} 2-\mathrm{Db}$ groove, results in a conformation of the TCR binding residues very similar to the wt peptide. Similarly, heteroclitic peptides of the Trp2 epitope show an identical pattern of contact points with the $\mathrm{H} 2-\mathrm{Db}$ of the wt peptide. Each 


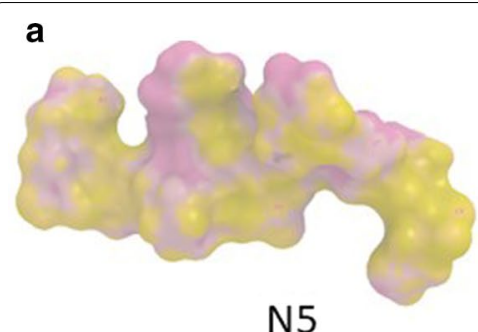

N5

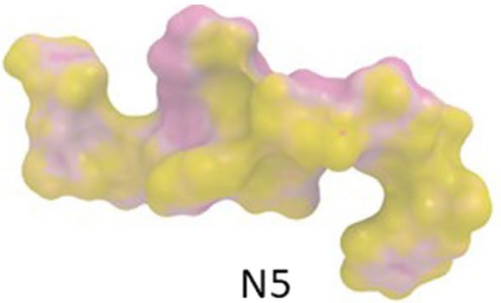

E7

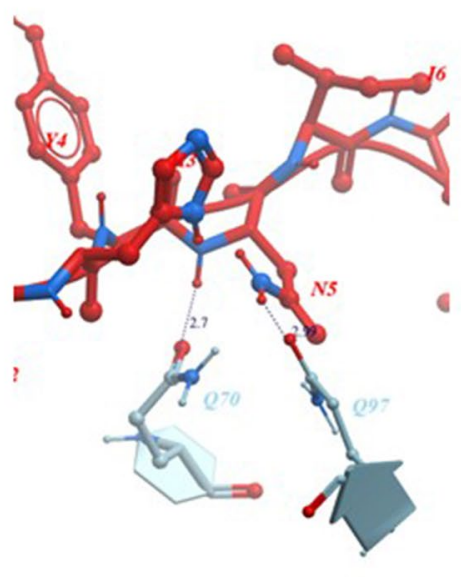

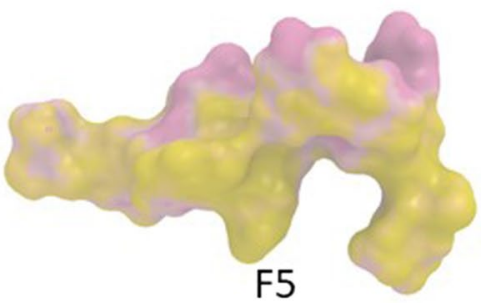

Trp2

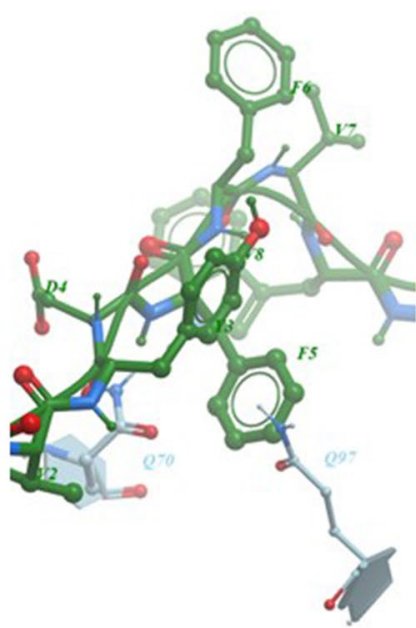

b

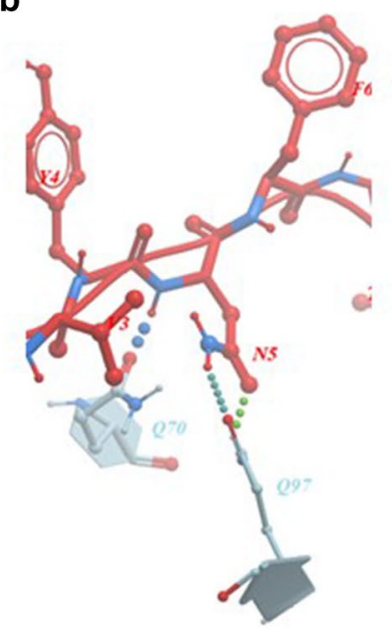

Fig. 4 Predicted peptide conformation. a, b The conformation of the wt HPV-E7 and Trp2 peptides, bound to the H2-Db molecule, is shown compared to the LCMV peptide KAVYNFATC ( $1 F G 2$, protein data bank). The amino acid at the anchor position 5 is highlighted for the three peptides. The presence of the non-polar Phenylalanine (Phe, F) in the Trp2 peptide results in a very poor binding to the H2-Db molecule, compared to the HPV-E7 and LCMV peptides

heteroclitic peptide, when docked into the $\mathrm{H} 2-\mathrm{Db}$ groove, shows a substantial similarity compared to the wt, except for the D4R and the D4W substitutions.

The binding assay confirm that the heteroclitic peptides of the E7 epitope, except for the Y4E substitution, showed a binding to the $\mathrm{H}-2 \mathrm{Db}$ stronger than the wt peptide, although the correlation with predicted binding was rather low. Similarly, most of the heteroclitic peptides of the Trp2 epitope showed a binding to the $\mathrm{H}-2 \mathrm{Db}$ stronger than the wt peptide, although the correlation with predicted binding was low.
In conclusion, we demonstrated that modified heteroclitic TAAs can be improved by changing even one single side chain of the TCR-binding residues, achieving higher affinity to major histocompatibility class I (MHC-I) molecule. Therefore, such a strategy may be very effective for designing vaccine antigens with superior antigenic efficacy.

In this respect, a validation experiment is currently planned in an animal model, to confirm the in silico analysis described in the present study. This will establish the foundation for moving forward the concept into a human clinical trial. 


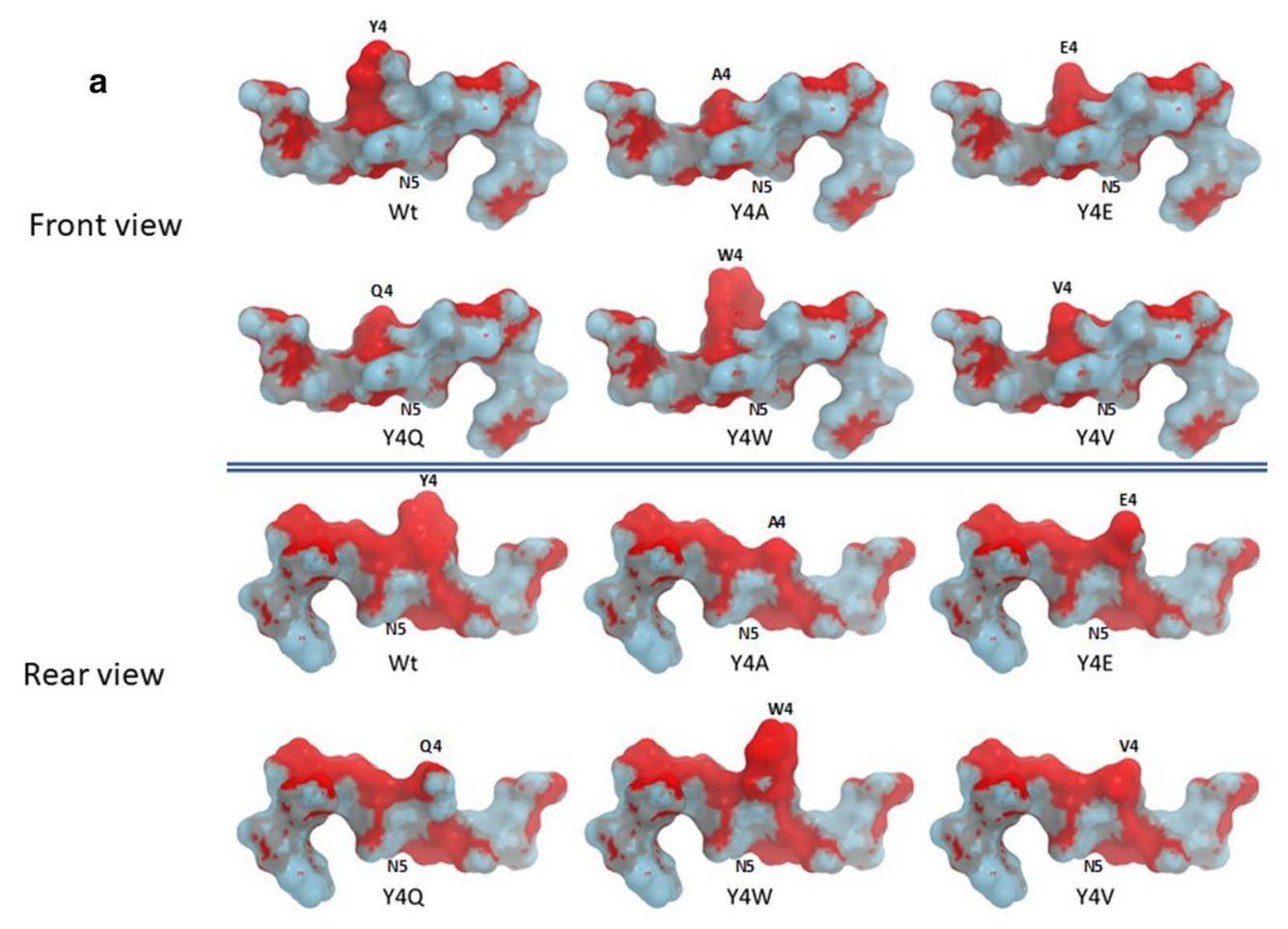

b

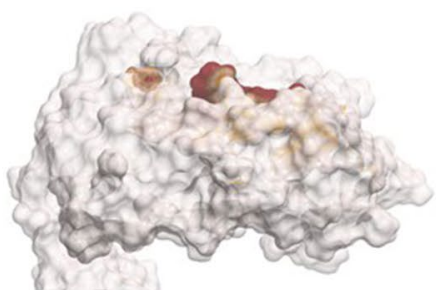

wt

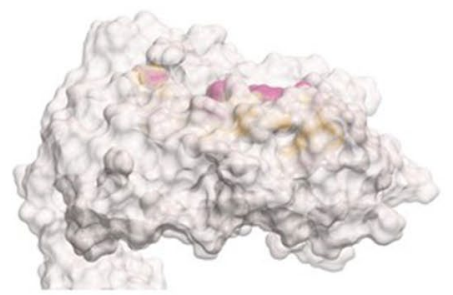

Y4A

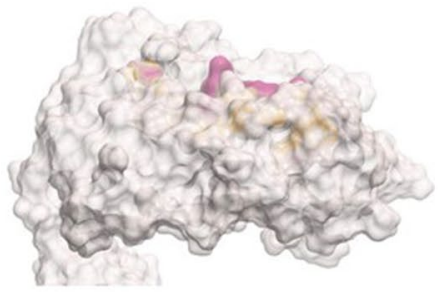

Y4E

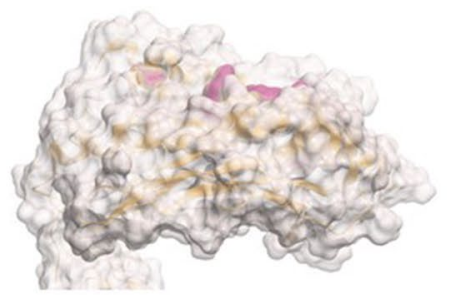

Y4Q

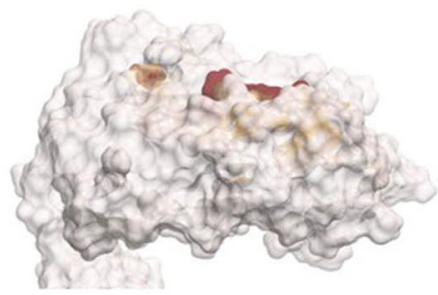

Y4V

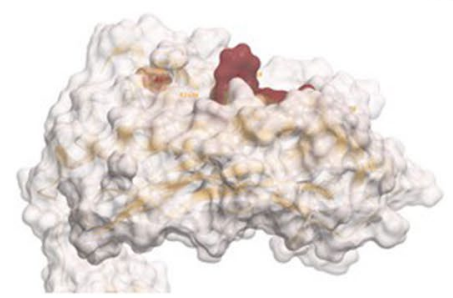

Y4W

Fig. 5 Predicted heteroclitic HPV-E7 peptides conformation. a The conformation of the heteroclitic HPV-E7 peptides, bound to the H2-Db molecule, is shown compared to the wt sequence. Contact pattern to the H2-Db are indicated in grey for both front and rear sides. $\mathbf{b}$ Prediction of the heteroclitic peptides'structure presented to the $C D 8^{+} \mathrm{T}$ cell for interaction with the TCR 


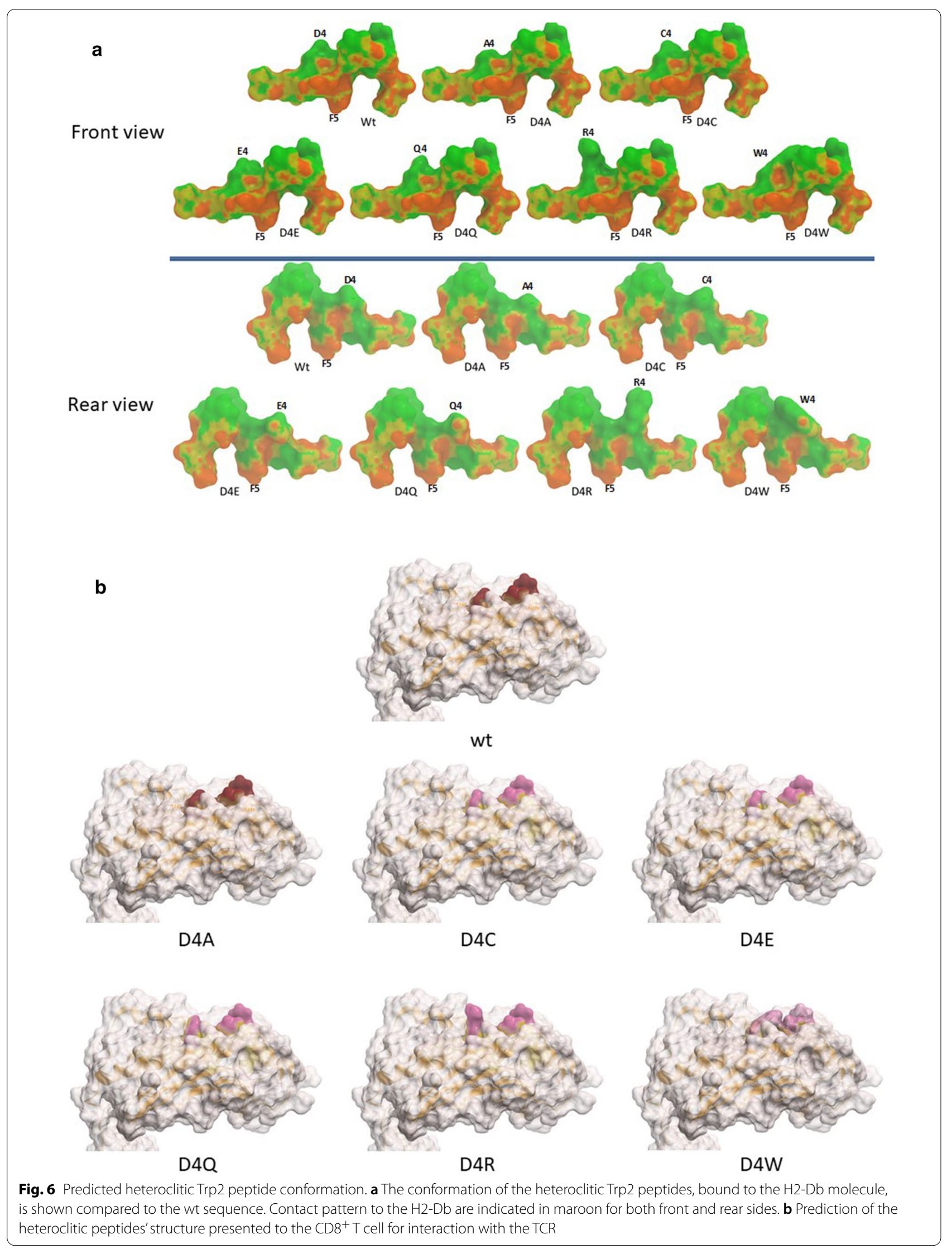



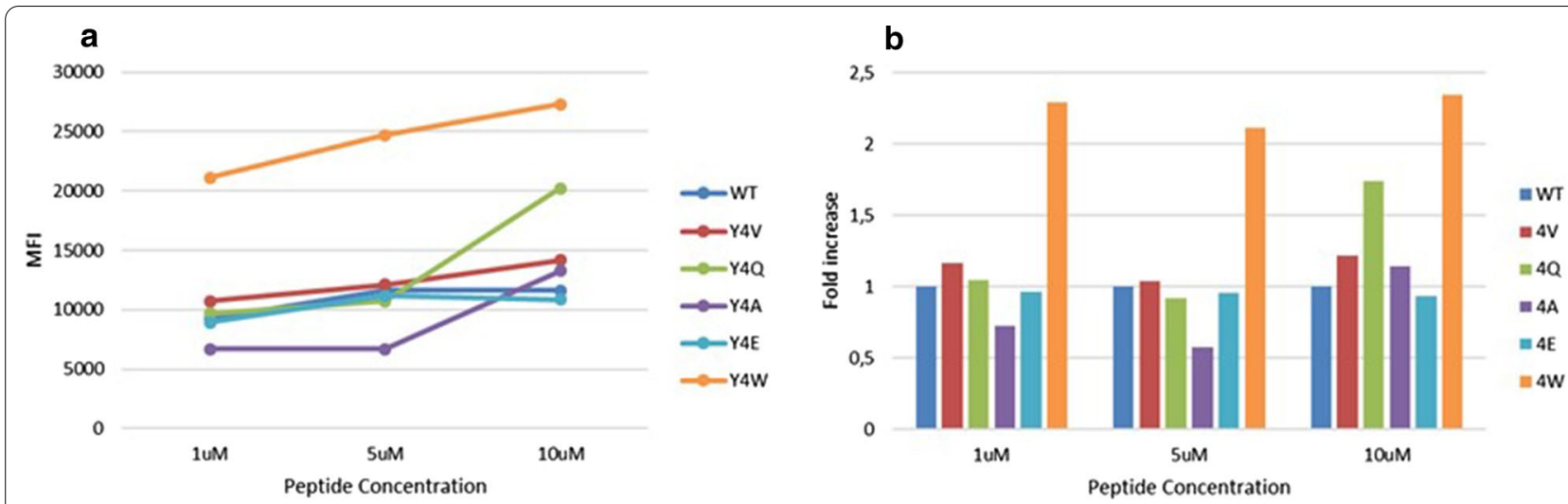

C

\section{d}
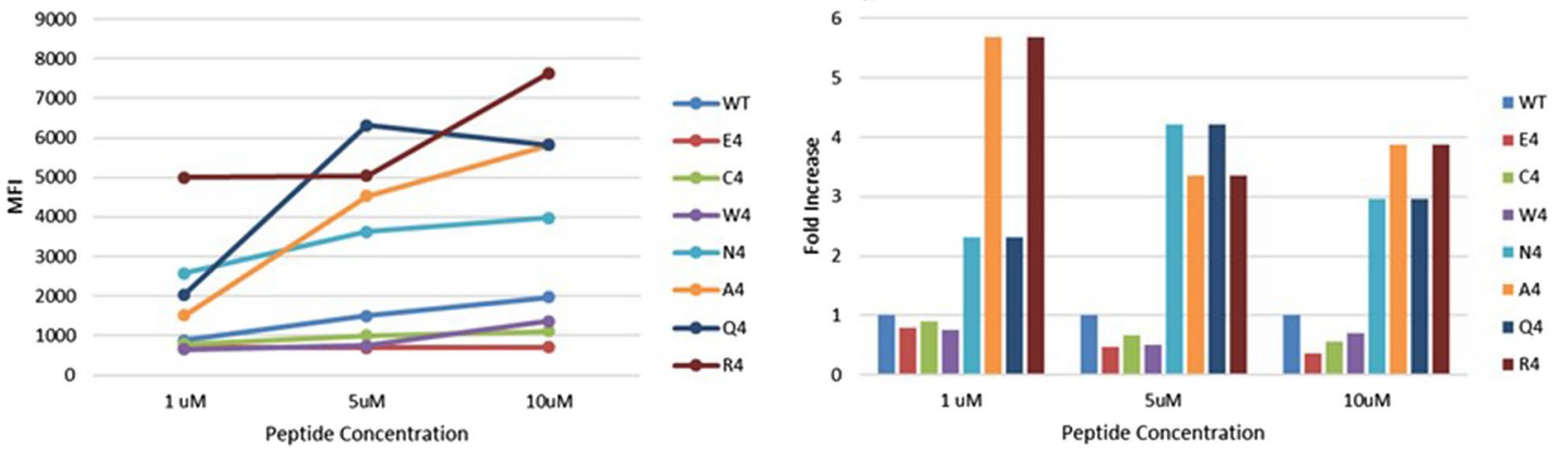

Fig. 7 Binding affinity to the $\mathrm{H} 2-\mathrm{Db}$ molecule. Binding to $\mathrm{H} 2-\mathrm{Db}$ molecule was assessed in TAP-deficient RMA-S murine cells loaded with the indicated peptides. a Mean fluorescence intensity at flow cytometer indicates binding levels of HPV-E7 wt and heteroclitic peptides to the H2-Db molecule at the different concentrations. $\mathbf{b}$ Fold-increase $(w t=1)$ of the binding to the $\mathrm{H} 2$-Db molecule of each heteroclitic peptides at the different concentrations. c Mean fluorescence intensity at flow cytometer indicates binding levels of wt and heteroclitic Trp2 peptides to the $\mathrm{H} 2-\mathrm{Db}$ molecule at the different concentrations. $\mathbf{d}$ Fold-increase $(\mathrm{wt}=1)$ of the binding to the $\mathrm{H} 2-\mathrm{Db}$ molecule of each heteroclitic peptides at the different concentrations

\section{Acknowledgements}

RMA-S cells were kindly provided by Prof. Thorbald van Hall, Leiden University Medical Center, the Netherlands. CINECA Supercomputing (ISCRA C project code HP10CXCABH—E7HPV) is acknowledged for computational support.

\section{Authors' contributions}

$B C$ and CR performed all the epitope conformation and in vitro validation; $\mathrm{AM}$ and AP performed bioinformatics predictions of binding affinity; CM provided technical support; LV contributed to the conformational analyses; MR supervised the optimization of the peptide synthesis; LB contributed to data analysis; MT designed the study, supervised the analysis and drafted the manuscript. All authors read and approved the final manuscript.

\section{Funding}

The study was funded by the FP-7 HEPAVAC (Grant nr. 602893) (LB); Transcan2-HEPAMUT project (Grant nr. 643638) (LB); Italian Ministry of Health through Institutional "Ricerca Corrente" (LB); POR FESR 2014/2020 "Campania OncoTerapie" (LB, LV, MR). AM is funded by "Ricerca Corrente". CM, BC; CR are funded by POR FESR 2014/2020 "NanoCAN".

\section{Availability of data and materials}

Data and material are available upon request.

\section{Ethics approval and consent to participate} Not applicable.

\section{Consent for publication}

The corresponding author has received consent for publication.

\section{Competing interests}

The authors declare no potential conflicts of interest.

\section{Author details}

${ }^{1}$ Innovative Immunological Models Lab, Istituto Nazionale Tumori "Fond.

G. Pascale", Via Mariano Semmola, 1, 80131 Naples, Italy. ${ }^{2}$ Institute of Biostructures and Bioimaging, CNR, Naples, Italy. ${ }^{3}$ Present Address: Istituto Di Cristallografia-CNR, c/o area Science Park S.S. 14 Km 163.5 Basovizza, 34149 Trieste, Italy.

Received: 8 February 2021 Accepted: 16 February 2021

Published online: 26 February 2021

\section{References}

1. Zhao J, Chen Y, Ding ZY, Liu JY. Safety and efficacy of therapeutic cancer vaccines alone or in combination with immune checkpoint inhibitors in cancer treatment. Front Pharmacol. 2019;10:1184.

2. Rammensee H, Bachmann J, Emmerich NP, Bachor OA, Stevanovic S. SYFPEITHI: database for MHC ligands and peptide motifs. Immunogenetics. 1999;50:213-9.

3. Rammensee HG, Friede T, Stevanoviic S. MHC ligands and peptide motifs: first listing. Immunogenetics. 1995;41:178-228.

4. Parker KC, Bednarek MA, Hull LK, Utz U, Cunningham B, Zweerink HJ, Biddison WE, Coligan JE. Sequence motifs important for peptide binding to the human MHC class I molecule, HLA-A2. J Immunol. 1992;149:3580-7. 
5. Hunt DF, Henderson RA, Shabanowitz J, Sakaguchi K, Michel H, Sevilir N, Cox AL, Appella E, Engelhard VH. Characterization of peptides bound to the class I MHC molecule HLA-A2.1 by mass spectrometry. Science. 1992;255:1261-3.

6. Chen JL, Stewart-Jones G, Bossi G, Lissin NM, Wooldridge L, Choi EM, Held G, Dunbar PR, Esnouf RM, Sami M, et al. Structural and kinetic basis for heightened immunogenicity of T cell vaccines. J Exp Med. 2005;201:1243-55.

7. Rosenberg SA, Yang JC, Schwartzentruber DJ, Hwu P, Marincola FM, Topalian SL, Restifo NP, Dudley ME, Schwarz SL, Spiess PJ, et al. Immunologic and therapeutic evaluation of a synthetic peptide vaccine for the treatment of patients with metastatic melanoma. Nat Med. 1998;4:321-7.

8. Houghton CS, Engelhorn ME, Liu C, Song D, Gregor P, Livingston PO, Orlandi F, Wolchok JD, McCracken J, Houghton AN, et al. Immunological validation of the EpitOptimizer program for streamlined design of heteroclitic epitopes. Vaccine. 2007:25:5330-42.

9. Petrizzo A, Caruso FP, Tagliamonte M, Tornesello ML, Ceccarelli M, Costa V, Aprile M, Esposito R, Ciliberto G, Buonaguro FM, et al. Identification and validation of HCC-specific gene transcriptional signature for tumor antigen discovery. Sci Rep. 2016;6:29258.

10. Dao T, Korontsvit T, Zakhaleva V, Jarvis C, Mondello P, Oh C, Scheinberg DA. An immunogenic WT1-derived peptide that induces $T$ cell response in the context of HLA-A*02:01 and HLA-A*24:02 molecules. Oncoimmunology. 2017;6:e1252895.

11. Bae J, Samur M, Munshi A, Hideshima T, Keskin D, Kimmelman A, Lee AH, Dranoff G, Anderson KC, Munshi NC. Heteroclitic XBP1 peptides evoke tumor-specific memory cytotoxic T lymphocytes against breast cancer, colon cancer, and pancreatic cancer cells. Oncoimmunology. 2014;3:e970914

12. Madura F, Rizkallah PJ, Holland CJ, Fuller A, Bulek A, Godkin AJ, Schauenburg AJ, Cole DK, Sewell AK. Structural basis for ineffective T-cell responses to MHC anchor residue-improved "heteroclitic" peptides. Eur J Immunol. 2015:45:584-91.

13. Dyson J. T-cell receptors: tugging on the anchor for a tighter hold on the tumor-associated peptide. Eur J Immunol. 2015;45:380-2.

14. Carrabba MG, Castelli C, Maeurer MJ, Squarcina P, Cova A, Pilla L, Renkvist N, Parmiani G, Rivoltini L. Suboptimal activation of CD $8(+) T$ cells by melanoma-derived altered peptide ligands: role of Melan-A/MART-1 optimized analogues. Cancer Res. 2003;63:1560-7.

15. Parkhurst MR, Salgaller ML, Southwood S, Robbins PF, Sette A, Rosenberg $S A$, Kawakami Y. Improved induction of melanoma-reactive CTL with peptides from the melanoma antigen gp100 modified at HLA-A*0201binding residues. J Immunol. 1996;157:2539-48.
16. Chen JL, Dunbar PR, Gileadi U, Jager E, Gnjatic S, Nagata Y, Stockert E, Panicali DL, Chen YT, Knuth A, et al. Identification of NY-ESO-1 peptide analogues capable of improved stimulation of tumor-reactive CTL. J Immunol. 2000;165:948-55.

17. Circelli L, Petrizzo A, Tagliamonte M, Heidenreich R, Tornesello ML Buonaguro FM, Buonaguro L. Immunological effects of a novel RNAbased adjuvant in liver cancer patients. Cancer Immunollmmunother. 2017;66:103-12.

18. Binkowski TA, Marino SR, Joachimiak A. Predicting HLA class I non-permissive amino acid residues substitutions. PLOS ONE. 2012;7:e41710.

19. Moise L, Gutierrez AH, Bailey-Kellogg C, Terry F, Leng Q, Abdel Hady KM, VerBerkmoes NC, Sztein MB, Losikoff PT, Martin WD, et al. The two-faced T cell epitope: examining the host-microbe interface with JanusMatrix. Hum Vaccinlmmunother. 2013;9:1577-86.

20. Birnbaum ME, Mendoza JL, Sethi DK, Dong S, Glanville J, Dobbins J, Ozkan E, Davis MM, Wucherpfennig KW, Garcia KC. Deconstructing the peptide-MHC specificity of T cell recognition. Cell. 2014;157:1073-87.

21. Stone JD, Chervin AS, Kranz DM. T-cell receptor binding affinities and kinetics: impact on T-cell activity and specificity. Immunology. 2009:126:165-76.

22. Hawse WF, De S, Greenwood Al, Nicholson LK, Zajicek J, Kovrigin EL, Kranz DM, Garcia KC, Baker BM. TCR scanning of peptide/MHC through complementary matching of receptor and ligand molecular flexibility. J Immunol. 2014;192:2885-91.

23. Caporale A, Doti N, Sandomenico A, Ruvo M. Evaluation of combined use of Oxyma and HATU in aggregating peptide sequences. J Pept Sci. 2017:23:272-81.

24. van Stipdonk MJ, Badia-Martinez D, Sluijter M, Offringa R, van Hall T, Achour A. Design of agonistic altered peptides for the robust induction of CTL directed towards $\mathrm{H}-2 \mathrm{Db}$ in complex with the melanoma-associated epitope gp100. Cancer Res. 2009:69:7784-92.

25. Tissot AC, Ciatto C, Mittl PR, Grutter MG, Pluckthun A. Viral escape at the molecular level explained by quantitative T-cell receptor/peptide/MHC interactions and the crystal structure of a peptide/MHC complex. J Mol Biol. 2000;302:873-85.

\section{Publisher's Note}

Springer Nature remains neutral with regard to jurisdictional claims in published maps and institutional affiliations.
Ready to submit your research? Choose BMC and benefit from:

- fast, convenient online submission

- thorough peer review by experienced researchers in your field

- rapid publication on acceptance

- support for research data, including large and complex data types

- gold Open Access which fosters wider collaboration and increased citations

- maximum visibility for your research: over 100M website views per year

At BMC, research is always in progress.

Learn more biomedcentral.com/submissions 